\title{
A Case Report on Kasabach Merrit Syndrome
}

\author{
TAREK AZAD ${ }^{1}$, RABIUL HASAN ${ }^{1}$, ACHIRA BHATTACHERJEE ${ }^{2}$, TAHMINA JAHAN CHOUDHURY ${ }^{3}$
}

\begin{abstract}
Kasabach Merritt syndrome (KMS) is an uncommon complication of large haemangioma in which there is thrombocytopenia and coagulopathy. We report a case of a new born male baby presented with a large haemangioma on the right upper extremity and his initial laboratory tests were consistent with consumptive coagulopathy. He was diagnosed as a case of KMS and treated with oral prednisolone.
\end{abstract}

\section{Introduction:}

Kasabach Merritt Syndrome is characterized by a rapidly developing hemangioma, thrombocytopenia, micro-angiopathic haemolytic anaemia and coagulopathy as a result of platelet and RBC trapping and activation of the clotting system within the vasculature of haemangioma ${ }^{1}$.

This phenomenon was first described in 1940 by Kasabach and Merritt who took care of an infant with a giant capillary hemangioma and thrombocytopenic purpura ${ }^{1}$.

It is a rare disorder that can affect the infants from the time of birth or may appear later in infancy as the vascular malformation grows. More than $80 \%$ cases occur within first year of life ${ }^{2}$. Male and females are equally affected ${ }^{1}$.

Lesions are distinctive vascular tumors typically superficial and solitary but may involve internal structures that include tufted angiomas and Kaposiform haemangio-endothelioma ${ }^{3}$.

KMS can be lethal. The estimated mortality rate ranges from $10-37 \%{ }^{4}$. Mortality and morbidity are usually associated with visceral involvement, haemorrhage related to aggressive invasion, profound thrombocytopenia, DIC, severe infections and iatrogenic complications ${ }^{4}$.

1. Associate professor, Paediatric Department, Jalalabad Ragib Rabeya Medical College.

2. IMO, Paediatric Department, Jalalabad Ragib Rabeya Medical College.

3. Asst. Registrar, Paediatric Department, Jalalabad Ragib Rabeya Medical College.

Correspondence: Dr. Tahmina Jahan Choudhury, Email : opitahmina_29@yahoo.com

\section{Case Report:}

A new born male baby, first issue of his nonconsanguineous parents presented with a large sized hemangioma on his right upper extremity and small hemangioma on the neck and on parietal region of the scalp. Baby was born before term at $30^{\text {th }}$ weeks of gestation by LUCS due to pre-mature rupture of the membrane. His mother was 25 year-old-lady with good general health and was on regular antenatal checkup. There was no family history of similar illness.

On examination baby was pre term, very low birth weight $1.25 \mathrm{~kg}$ with large, solitary $20 \mathrm{~cm} X 10 \mathrm{~cm}$ sized erythematous induration on the right upper extremity. Two other indurations were noted on the neck $(3 \times 2 \mathrm{~cm}$ sized) and parietal region of the scalp $(2 \times 1 \mathrm{~cm}$ sized). These lesions were diagnosed as hemangioma.

The initial laboratory data revealed normocytic normochromic anaemia( $\mathrm{Hb} \% \quad 10.5 \mathrm{gm} / \mathrm{dl})$, thrombocytopenia (Platelet count $80,000 /$ cumm of blood). Other laboratory results including WBC counts, bleeding time, clotting time, activated partial thromboplastin time (APTT), prothombin time were within the normal range. Patient was diagnosed as Kasabach Merritt syndrome from a pre-existing hemangioma, clinical findings and laboratory values.

Baby was managed with blood transfusion and oral prednisolone. Seven days after initiating treatment his platelet count was increased and lesion ceased to expand. Then dose of the prednisolone was subsequently tapered. 


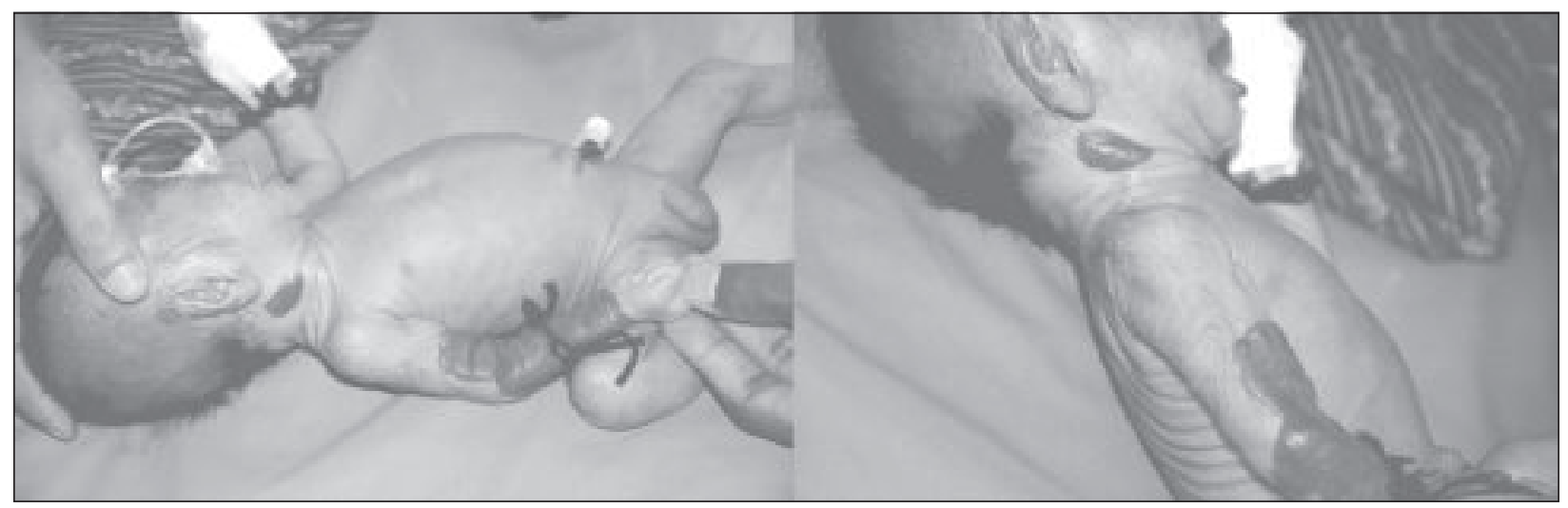

Fig.-1

\section{Discussion:}

Haemangioma is a commonly encountered benign vascular neoplasm. It is the most common soft tissue neoplasm of infancy ${ }^{5}$. KMS is a coagulopathy consisting of intravascular coagulation, clotting and fibrinolysis within the haemangioma. The trigger factors for the development of KMS include surgical intervention, pregnancy, angiography and needle aspiration of haemangioma ${ }^{6-8}$.

The pathogenesis of KMSin yet to be established. However, platelet trapping by abnormally proliferating endothelium within the haemangioma has been proposed as a possible mechanism ${ }^{9}$. Platelet trapping can result in the activation of platelets with secondary activation of coagulation cascades, eventually leading to consumption of various clotting factors. In addition to platelet trapping, excessive blood flow and sheer stress secondary to arteriovenous shunts within the tumor may cause further platelet activation. Both thrombocytopenic status and reduction in coagulation factors eventually result in bleeding within the tumors that manifests as a rapidly growing hemangioma.

Management of KMS has been challenging because of its rarity and there are no well established systemic treatment strategies. Systemic corticosteroid is considered to be first line therapy in patients with $\mathrm{KMS}^{10-12}$. If a lesion responds to steroid, the dose should be reduced slowly to prevent recurrence. The mechanism of prednisolone in controlling thrombocytopenia, coagulopathy and stabilization of hemangiomas remain unclear, although it appears to increase platelet, increase vasoconstriction, inhibit fibrinolysis and disrupt angiogenesis.

In cases resistant to systemic corticosteroid, multiple treatment modalities can be used in a stepwise manner, including interferon-alpha, an antiproliferative and antiangiogenic agent and vincristine, a strong inhibitor of angiogenesis. Radiotherapy is another option which can induce embolization within the hemangioma. These options are usually recommended as second line therapies ${ }^{9-12}$.

\section{References:}

1. Kasabach HH, Merritt KK. Capillary hemangioma with extensive purpura: report of a case. Am J Dis Child 1940; 59:1063-70.

2. Martins AG. Hemangioma and thrombocytopenia. J Pediatric Surgery. 1970; 5:641648[Pub Med].

3. Beutler E, Lichtman MA, Coller BS, Williams WJ. Williams Hematology. $6^{\text {th }}$ edn. Newyorj: McGraw-Hill; 2001; pp 110-113.

4. eMedicine.medscape.com, article/ 202455, overview.

5. Vilanova JC, Barcelo J, Smir Niotopoulos JG, Perez AR, Vilalon M, Miro J et al. Hemangioma from head to toe. MR imaging with pathologic correlation. Radiographics 2004; 24:367-85.

6. Esterly NB. Kasabach Merritt Syndrome in infants. AM J Dermatol. 1983;8:505513.[PubMed]

7. Karabocuglu M, Basarer N, Aydogan U, Demirkol M, Kurdogklu G, Neyzi O. development of Kasabach merritt Syndrome following needle aspiration of hemangioma. Pediatric emerg Care 1992;8:218-220.[Pub Med]

8. Jona JZ Kwaan HC. Bjelan M Raffensperger JG. Disseminated intravascular coagulation after 
excision of giant hemangioma. Am J Surg. 1974;127:588-592[Pub Med]

9. Hall GW. Kasabach merritt syndrome: Pathogenesis and management. $\mathrm{Br} \mathrm{J}$ Haematol. 2001;112:851-862[Pub Med]

10. Shin HY, Ryu KH, Ahn HS. Stepwise multimodal approach in the treatment of Kasabach merritt Syndrome. Pediatric Int 2000; 42:620-624.
11. Wananukul S, Nuchprayoon I, Seksarn P. treatment of Kasabach merritt Syndrome; A stepwise regimen of prednisolone, dipyridamole and Interferon. Int J Dermatol 2003; 42:741748[Pub Med].

12. Rodriguez V, Lee A, Witman PM, Anderson PA. Kasabach merritt phenomenon: Case series and retrospective review of the Mayo Clinic experience. J Pediatr Hematol Oncol. 2009; 31:522-526[Pub Med]. 